\title{
Investigation of the yeast dough mixing process at different rotational frequency of the mixing blade
}

\author{
Vitalii Rachok, Volodymyr Telychkun, Yuliya Telychkun
}

National University of Food Technologies, Kyiv, Ukraine

Keywords:

Kneading

Yeast

Dough

Rotation

Frequency

Humidity

\section{Article history:}

Received 31.05.2017

Received in revised form 30.06.2017

Accepted 05.09.2017

\section{Corresponding author:}

Vitalii Rachok

E-mail:

RachokV3478@gmail.com

DOI: $10.24263 / 2310-$

1008-2017-5-1-14

\section{Abstract}

Introduction. It was considering consider the question of mixing the yeast dough with the variable speed of rotation of the working element and the different humidity of the dough.

Materials and methods. The research was carried out by measuring the power and other parameters of kneading and recording the results in the form of pharynograms. Flour, water, salt and yeast blend was placed in a stirring chamber and recorded the torque and the corresponding technological parameters. The mixing of the yeast dough took place for 20 minutes for the rotational speed of the working element from 20 to 140 turns per minute and at different humidity levels of the dough in the range from $40,3 \%$ to $44,3 \%$.

Results and discussion. There have been stages of mixing the yeast dough investigated. The influence of reinforced mechanical processing on the yeast dough was studied. It has been established that with increasing the frequency of rotation, the time required for mixing the components decreases. At dampness of a dough 44,3\% at any speed of a rotation, in a range from 20 to $140 \mathrm{rpm}$. After intensive mechanical treatment of the yeast dough with a rotational speed of 60 to $140 \mathrm{rpm}$, it is required on its own batch of dough at different humidity, ranging from 40 to 60 seconds. Time is required for the third stage of kneading (dough plasticization), for the dough humidity of 40,3-42,4\% ranges from 160 to 180 seconds for the rotational speed of 60-80 revolutions per minute.

The required, fine-grained and uniformly distributed porosity (the number of portions of $4500-4800$ pieces) is observed in the intensive process of mixing the yeast dough for the rotational speed of the working body of 60 revolutions per minute. The highest porosity indices in the finished product for the parameters of the technological process of the rotational speed $(\mathrm{n}=60 \mathrm{rpm})$, the moisture content of the yeast dough $(\mathrm{H}=44,3 \%)$ under the given conditions, the porosity of the finished product $(\mathrm{P}=70 \%)$ reaches the maximum values.

Conclusions. The yeast dough mixing process should be carried out at relatively high turns of the working element $60-80 \mathrm{rpm}$, so the humidity in the specified ranges (40,3$44,3 \%$ ) will not significantly affect the process, the gluten macromolecule under the influence of internal stresses, arising in the dough, are partially destroyed, but due to the internal restructuring of the structure are restored again, and the gluten turns out to be elastic. 


\section{Introduction}

The dough kneading is an important technological operation. The duration of kneading for the wheat dough is from 1 to 20 minutes [1-3]. The purpose of kneading is to obtain a homogeneous dough mass with certain structural and mechanical properties [2].

There is the so-called two-stage model of mixing the dough, edited by the scientist Gaponyuka. There are two stages of the dough mixing: mixing components and plasticization. Bakers and chemistry specialists use the five-stage model of dough mixing edited by Kenneth J. Valence, Enrique Rothstein, R. Paul Singh [5].

To facilitate the analysis of the regularity of the mixing process and to identify the progressive rational parameters of its provision, O. Lisovenko proposed a three-stage model of the dough mixing (mixing of components, actually baking and plasticization), which is also based on modern developments of HD Cheshner, N. Kwenda and others $[8,10]$.

The dough formation during batching occurs as a result of a number of processes, of which the most important are: physical-mechanical, colloidal and biochemical processes. All these processes take place simultaneously, mutually affect each other and depend on the duration of batching, temperature and the quantity and quality of the raw materials used in batch testing [17-18].

Physic mechanical processes occur during kneading under the influence of a kneading element that mixes flour particles, water, yeast and additional raw materials, ensuring the interaction of all the constituent components [20].

Colloidal processes are connected with the main components of flour - proteins and starch. Proteins of wheat flour, absorbing moisture, sharply increase in volume and form a glutinous skeleton, inside of which there are swollen grains of starch and shell particles. As a result, Sticking of particles into a continuous mass leads to the formation of a test [3].

The physical dough properties are mainly determined by the specific features of its protein part. They determine the elasticity, ductility and viscosity of the wheat dough. However, excessive batching can cause destruction of the already formed dough structure, which can lead to a deterioration in the quality of bread [3-7].

During the batch of the dough, biochemical processes, caused by the action of enzymes of flour and yeast, also occur. The main biochemical processes are the hydrolytic decomposition of proteins under the action of proteolytic enzymes (proteolysis) and starch under the action of amylolytic enzymes (amylolysis). As a result of these processes, the amount of substances capable of transitioning to the liquid phase of the test increases, which leads to a change in its structural and mechanical properties [10].

One way to intensify the maturation of the dough is to increase the mechanical processing of the dough [20].

The purpose of the scientific study of mixing the yeast dough is to set the time limits of the mixing yeast dough stages length with different humidity $(40,3 \%, 42,4 \%, 44,3 \%)$, depending on the rotation frequency of the working parts.

\section{Materials and methods.}

The process of kneading of wheat yeast dough was reseached.

The research was carried out on FARINOGRAPH ${ }^{\circledR}-A T$, produced by German company BRABENDER ${ }^{\circledR}$, the next generation of high-precision instruments for the flour quality and the dough behavior study during its mixing determining, depending on the dipping time and the rotation frequency of the mixing blade. 
Fill your flour sample into the preheated and temperature controlled measuring mixer. At the start the program the mixer blades loosen up the flour and a minute later the water will be injected into the mixer. A dough develops, which is subjected to a defined mechanical stress by the rotating mixer blades which are driven by a motor, carried in a pendulum bearing. The resistance of the dough against the blades, which depends on the viscosity of the dough, causes an opposite deflection of the motor housing. This deflection is measured as torque and recorded and plotted online as a function of time in a clear color diagram.

To assess the porosity of the finished products wiring was cutting, and photographed via "ImageJ". Then porosity of the finished product were calculated through the found and counting the number of pores. "ImageJ - the image processing software, which can calculate the area and degree of image details, user-defined election statistic, measure distances and angles, a histogram density and line profile plots.

\section{Result and discusion}

After 1-2 minutes dough mixing, the curve reaches a certain maximum. This characterizes the transition of the mixing raw material to the condition of the bound mass and shows the duration of the 1st stage of the components mixing process (Figure 1). During the subsequent mixing process the dough mass acquires a certain elasticity. This is due owing to swelling processes and action of hydrolytic enzymes. The curve reaches a second maximum that characterizes the duration of the 2nd stage of the process (Figure 2). This process is called the actual metaphase. The next stage is plasticization (Figure 3), during which the effective viscosity of the test decreases. The total duration of the first and second stages is called the dough formation process. During this period, processes of swelling dominate. As a result of deepening processes of enzymatic and mechanical disaggregation of proteins, there is a gradual dilution of the consistency of the dough.

We investigated the first stage (Figure 1) of yeast dough components stirring. The graph shows that the first stage is linear. As the rotation frequency increases, the time required for components mixing decreases. On the moisture content of the dough $44,3 \%$ at any rotation speed, in the range from $20 \mathrm{rpm}$ to $140 \mathrm{rpm}$. The regularity of the effect of humidity on the yeast dough mixing process is due to the fact that when more water is added, contact with bulk substances takes place in a much shorter time (50-60 seconds) and there is a qualitative mixing of the components.

The second stage of mixing, actually the dough dipping (Figure 3), depending on the rotational frequency and the different dough humidity, is of a power character and is inversely proportional to the first stage in duration. This process is explained by the fact that $40,3 \%$ of the dough humidity contains up to a relatively less amount of water and, thus, the dough framework is formed more quickly. With increased machining by working parts from $60 \mathrm{rpm}$ to $140 \mathrm{rpm}$, the time required for the actual dough mix at a different humidity is $40-60$ seconds.

It was investigated that the physical properties of the yeast dough during mixing are continuously changed as a result of a number of processes that occur when kneading the dough. The time is required for the third stage of the dough plastification with the humidity $40,3-42,4 \%$ is $160-180$ seconds at a rotational speed of $60-80 \mathrm{rpm}$. 


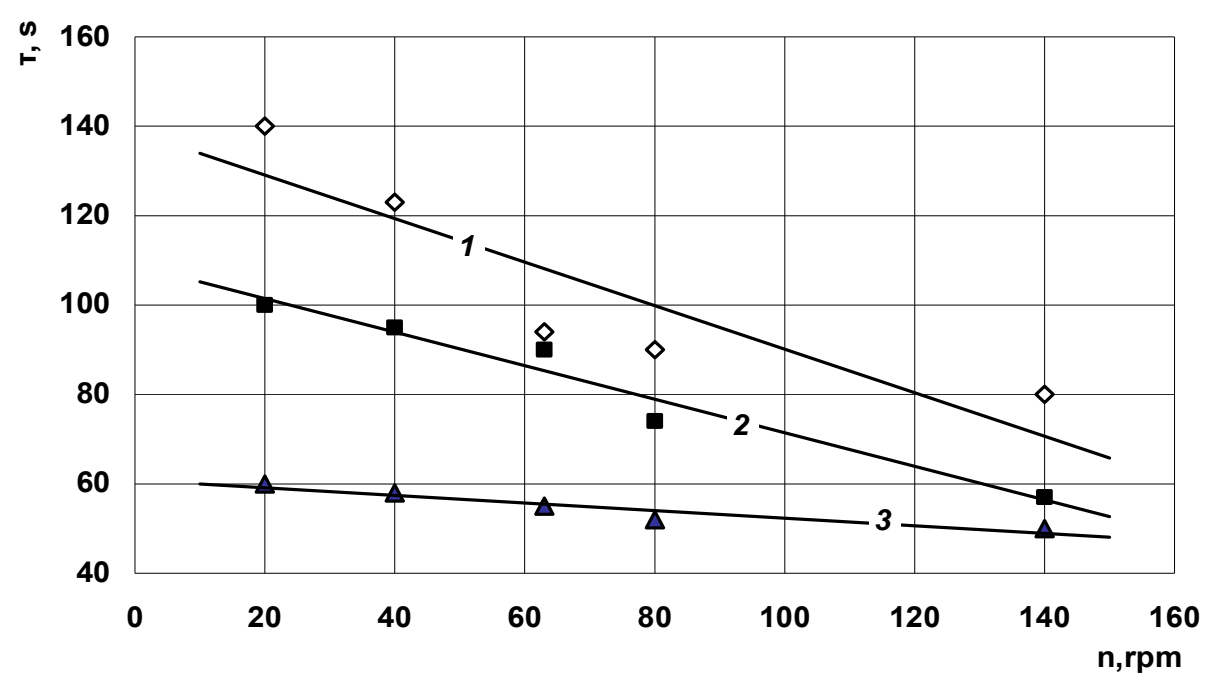

Figure 1. The first mixing stage duration, depending on the frequency of rotation and the different humidity: $1-40,3 \% ; 2-42,4 \% ; 3-44,3 \%$

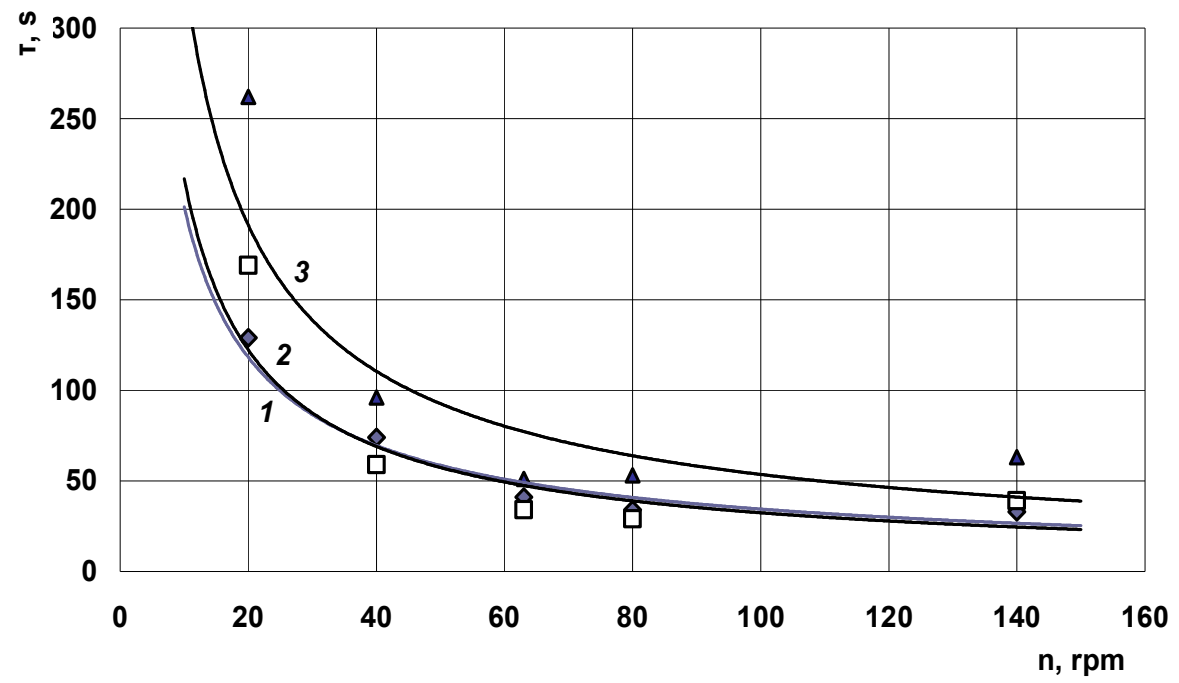

Figure 2. The second stage of mixing duration depending on the frequency of rotation and the different humidity: $1-40,3 \% ; 2-42,4 \% ; 3-44,3 \%$ 


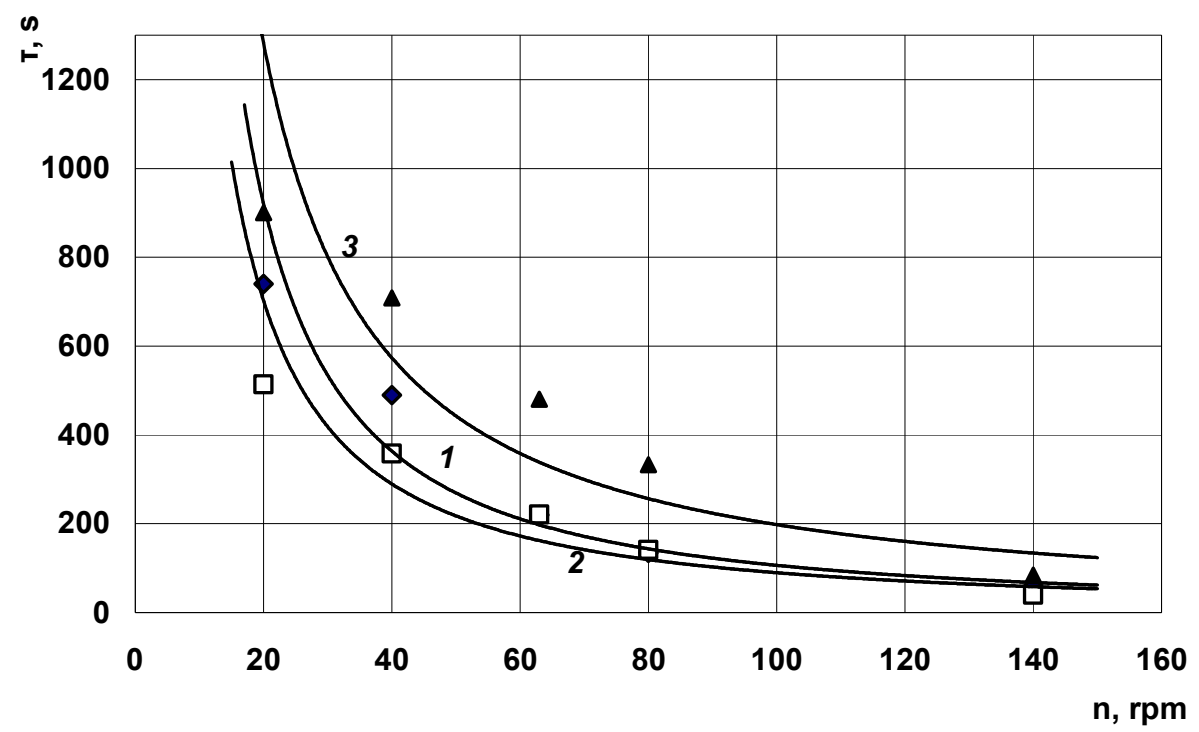

Figure 3. Duration of mixing the third stage, depending on the rotational speed and humidity: $1-40,3 \% ; 2-42,4 \% ; 3-44,3 \%$

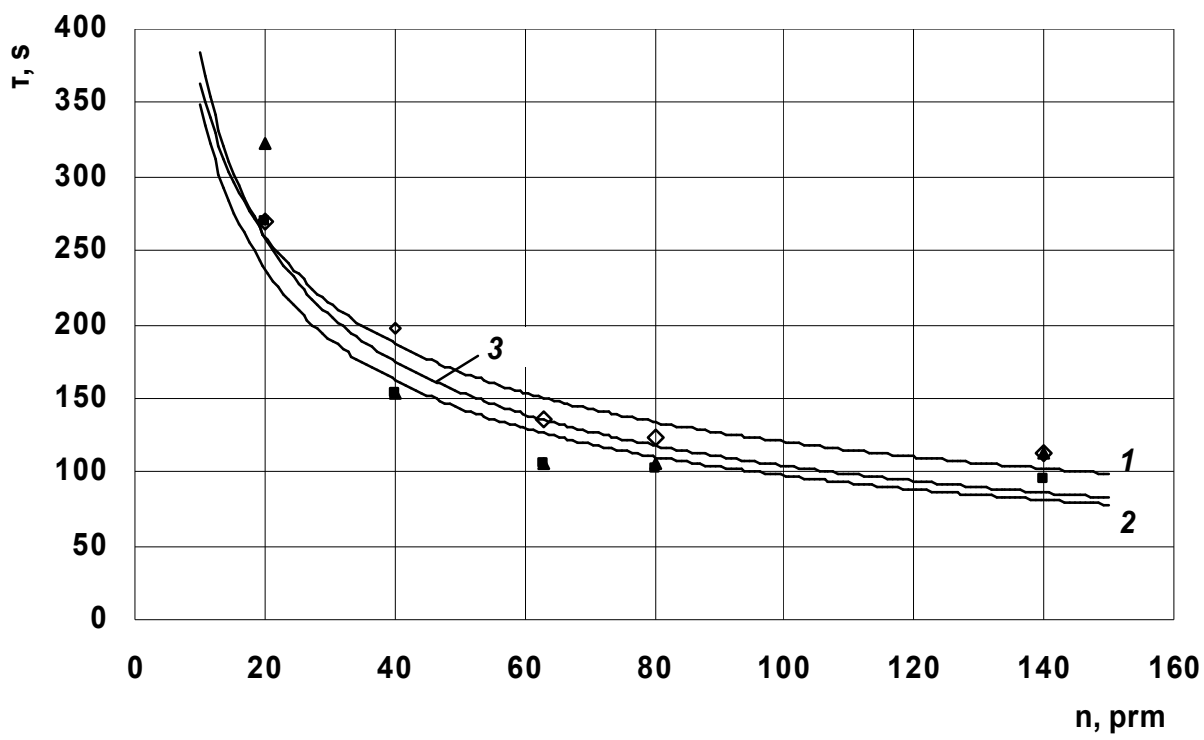

Figure 4. The dough formation time with different humidity $(1-40,3 \% ; 2-42,4 \% ; 3-44,3 \%)$ and rotation frequency 
The time of dough formation at different humidity and speed of rotation is shown on Figure 4, the lines have a degree of power. Dependence analysis of the duration of the dough formation indicates that the determining factor in the dough formation is the intensity of mechanical treatment, thus increasing the rotational speed of the working element reduces the time required for the dough formation.

The dependence of the duration of the dough formation, depending on the frequency of rotation, shows that with a rotational speed of the working element of $140 \mathrm{rpm}$, the duration of the dough formation will be the smallest, the same indicators of 100 seconds of time required for the dough formation are observed and with a rotational speed of 60-120 rpm. Rapid dough formation is due to the fact that the intensity of mixing at such rotations of the working organ is high. After analyzing the results, it is advisable to mix the yeast dough at the rotational speed of the working element of 50-60 rpm, increase the rotational speed of the working element above the parameters is not meaningful, since the time will be the same but the energy required for the batch, will be used more.

Mechanical processing of the dough during batching and transportation is one of the main ways of regulating its rheological properties. To mix the bread dough different types of machines are used with different working elements, which depending on the type of flour, formulation composition and assortment features carry out a different mechanical effect on the dough.

We have been conducting studies of torque change over time by mixing the yeast dough with different humidity $(40,3 \%, 42,4 \%, 44,3 \%)$ for different working element rotation (from $20 \mathrm{rpm}$ to $140 \mathrm{rpm}$ ). The torque was automatically detected by means of sensors in real time.

The yeast dough was added to Farinograph for 20 minutes. The results of a series of studies were given in the form of three diagrams (Figure 5,6,7).

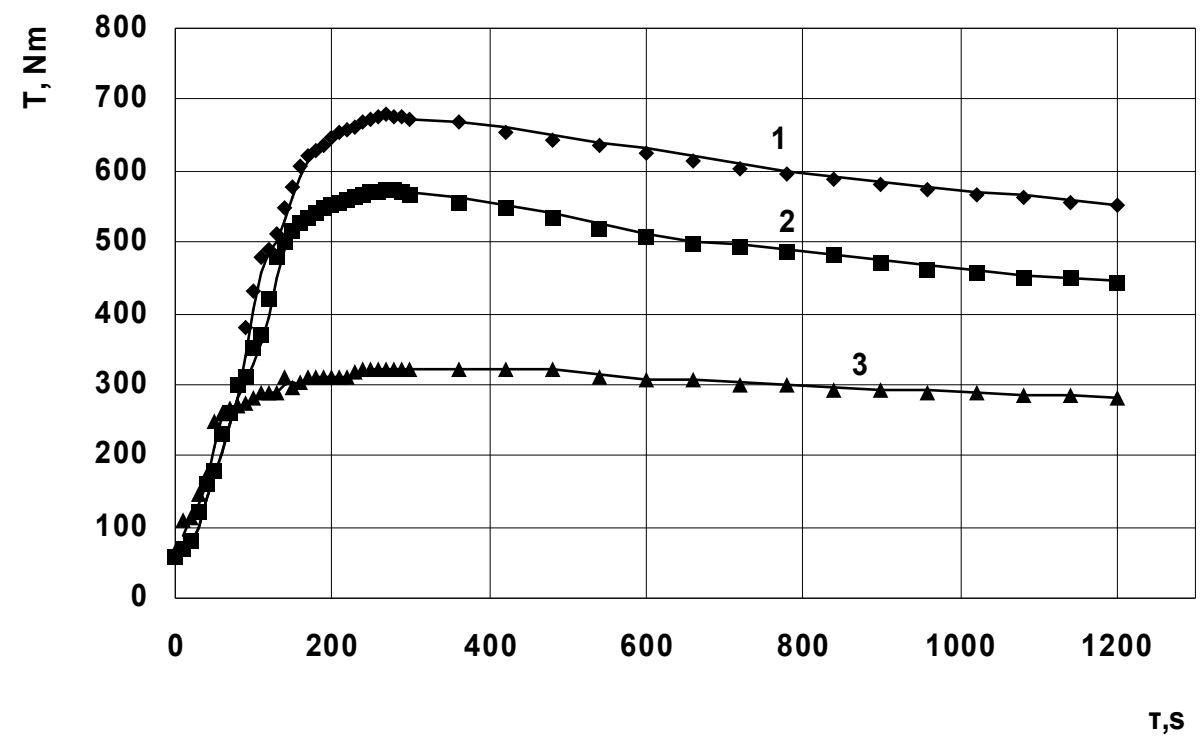

Figure 5. Dependence of torque on humidity in time $(1-40,3 \% ; 2-42.4 \% ; 3-44,3 \%)$ at constant speed $(20 \mathrm{rpm})$ 
The obtained dependence (Figure 5) shows that the yeast dough has a different formation time at a different humidity at a constant rotational speed $(20 \mathrm{rpm})$. High figures $(690 \mathrm{Nm})$ of torque are observed when kneading the yeast dough, humidity $40,3 \%$ for a 300 second pickup, where we observe the second stage of mixing - kneading. The mixing of the yeast dough with a humidity of $44,3 \%$ proceeds for the indicators of the torque of the working element at the limit of $300 \mathrm{Nm}$, thus the electricity consumption significantly reduces and the drive works in a stable load. On the graph (Figure 5) it is seen that the torque increase reaches its maximum values at the second stage of mixing, and then gradually decreases.

At the rotational speed of the working element, $60 \mathrm{rpm}$, the torque dependence (Figure 6) for the different moisture content of the yeast dough, the following dependence is observed: at the first stage (mixing of the components), the torque increases, after which the second stage (the actual batch) begins to reach the maximum on the graph. After that the torque decreases and the third stage (plasticization) of the kneading of the yeast dough occurs. An interesting feature for the rotational speed $(60 \mathrm{rpm})$ of the working element is that the torque is the same when the humidity is $40,3-42,4 \%$ after 650 seconds.

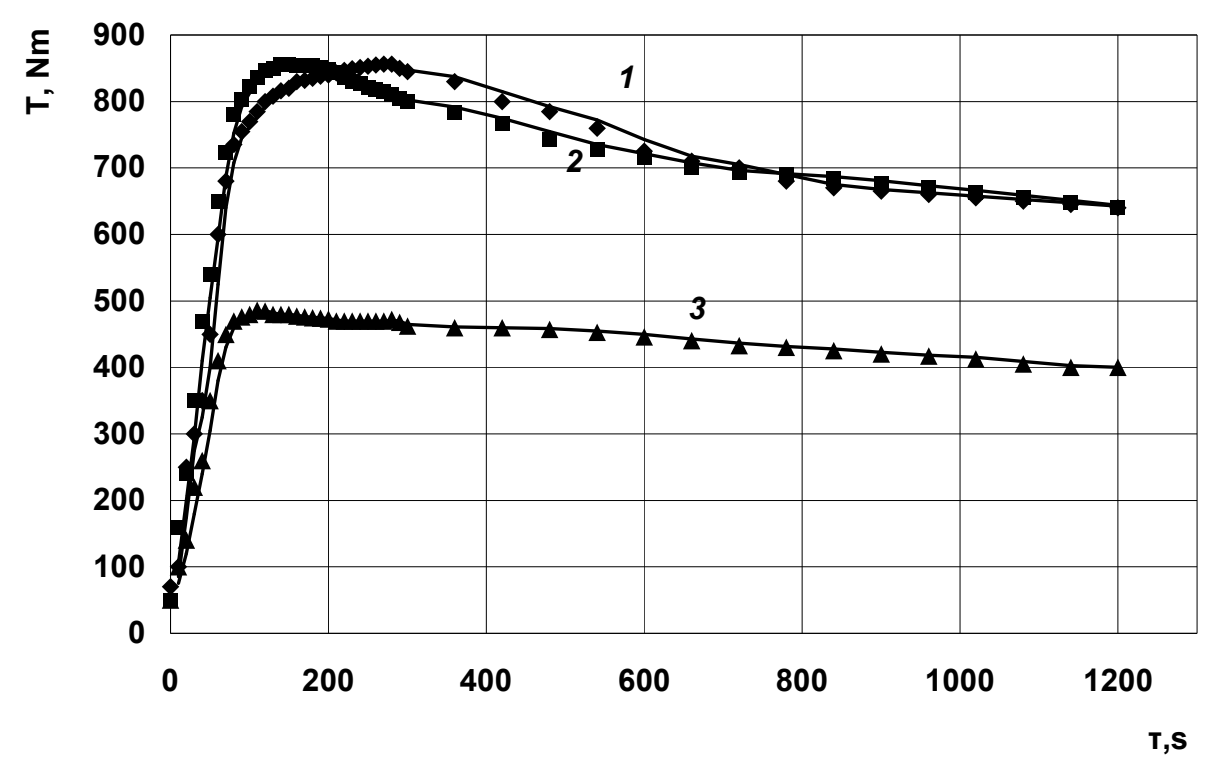

Figure 6. Torque dependence on humidity in time (1-40.3\%, 2-42.4\%, 3-44.3\%) at constant speed of rotation $(60 \mathrm{rpm})$

The highest torque (Figure 7) is observed when mixing a yeast dough with a rotational speed of the working element of $140 \mathrm{rpm}$ and a test dough of $40,3 \%$ of the torque value reaching $1180 \mathrm{Nm}$, thus the most load on the working element occurs and the result is consumed according to these parameters more electricity.

The maximum torque at a humidity of $42,4 \%$ is observed at $980 \mathrm{Nm}$, and then rapidly falls at the stage of plasticization. The process of mixing the yeast dough at a humidity of $44,3 \%$ rises to a mark of $430 \mathrm{Nm}$ and then goes very slowly down to the $395 \mathrm{Nm}$ mark. 


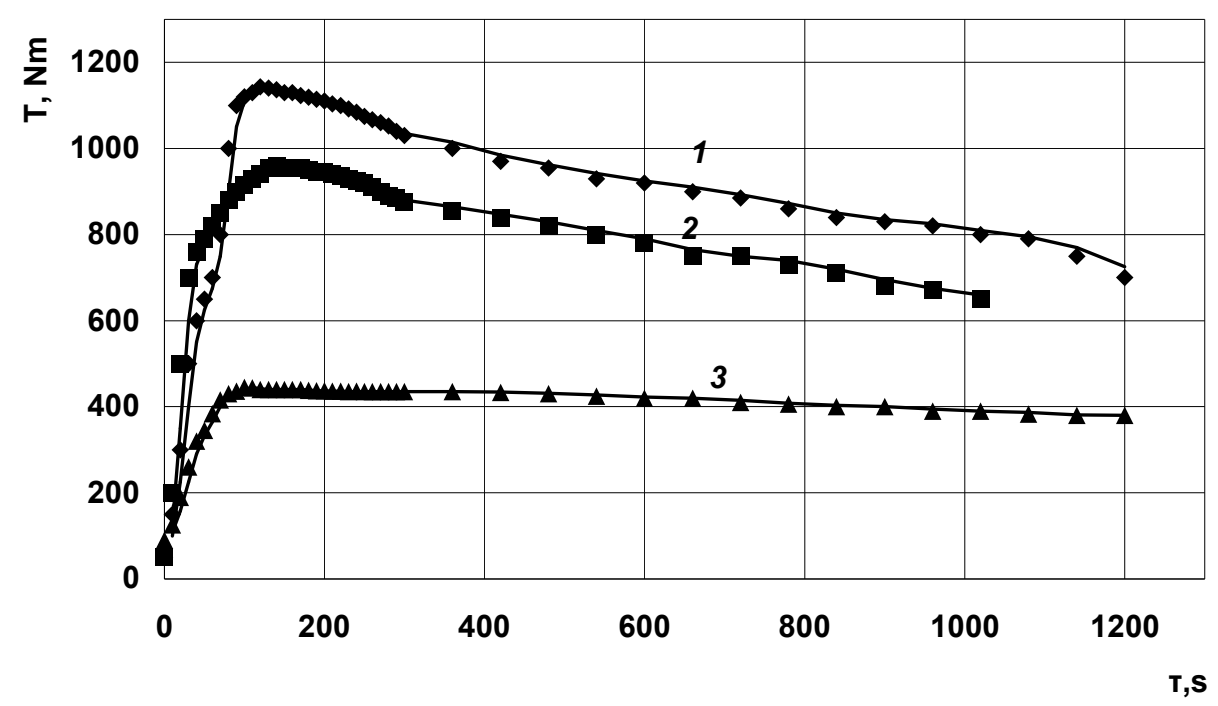

Figure 7. Torque dependence on humidity in time $(1-40,3 \% ; 2-42,4 \% ; 3-44,3 \%)$ at constant speed $(140 \mathrm{rpm})$

The process of yeast dough mixing at the rotational speed of the working element of $140 \mathrm{rpm}$ is not feasible, as high torque values are observed, which in turn increases the cost of electricity. For the rotational speed of the working element of $20 \mathrm{rpm}$, the process of kneading the yeast dough proceeds slowly. The speed of rotation of $60 \mathrm{rpm}$ is rational at a given speed of rotation, but comparatively low torque is observed, but at the same time

The porosity of the finished product (Figure 8) is the volume of pores, expressed as a percentage of the total volume of crumb of bread. Bread with uniform fine porosity, well loosened is better impregnated with digestive juices and therefore is better absorbed.

Good, fine-grained and uniformly distributed porosity (the number of portions of 4500 4800 pieces) is observed in the intensive process of mixing the yeast dough for the rotational speed of the working element of $60 \mathrm{rpm}$. At rotational speeds of $20 \mathrm{rpm}$, in some places large pores are formed that occupy a large area in the volume of the finished product and thus interfere with the formation of a fine-grained structure of porosity (the number of portions is $2990-3120$ pieces). The nature of the distribution of porosity in the finished product for the rotational speed of the working element $140 \mathrm{rpm}$ and 40,3\% moisture content is not accompanied by a uniform distribution of porosity (the number of portions of 2600 pieces), due to the fact that during intensive yeast dough mixing at a relatively low humidity the gluten-free dough frame collapses. At a rotational speed of $140 \mathrm{rpm}$ and a moisture content of $42,4-44,3 \%$ of yeast dough, uniform fine grained porosity is observed (the number of pores is 3080-3089 pieces).

The amount of pores of the finished product (Figure 9) characterizes an important quality parameter of the bread property. Low porosity is usually inherent in bread from poorly mixed dough. The porosity of wheat bread is $50-70 \%$, depending on the type of bread and the way it is baked. We determine the porosity using the "ImageJ" software package. 


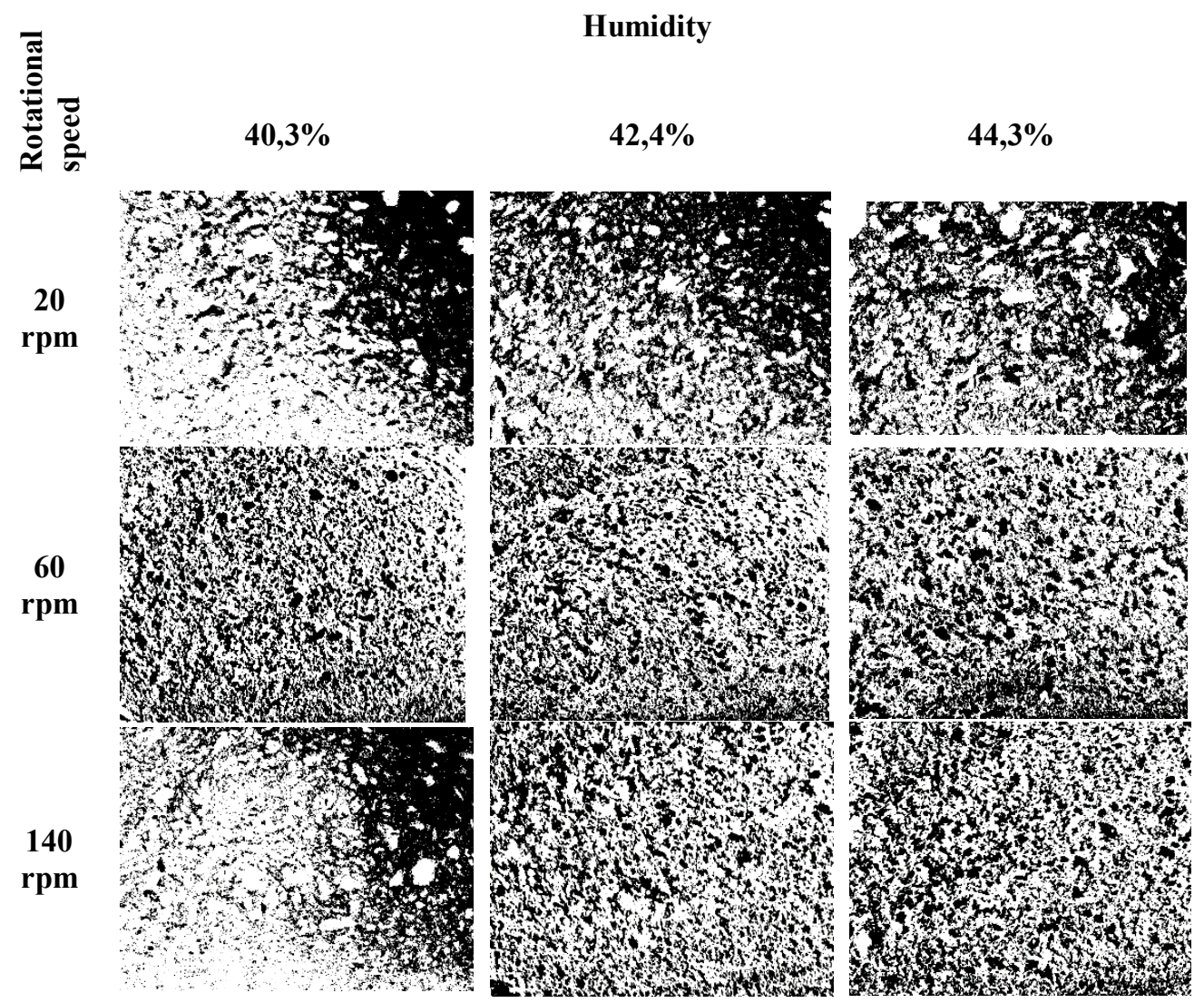

Figure 8. Digital image of the porosity of the finished product at different rotational speed and dough moisture humidity

The best porosity indicators in the finished product for the parameters of the technological process are the rotation frequency $(\mathrm{n}=60 \mathrm{rpm})$, humidity of the yeast dough $(\mathrm{H}=44,3 \%)$, under these conditions, the porosity of the finished product $(\mathrm{P}=70 \%)$ reaches the maximum values. Good indicators of porosity of the finished product $(\mathrm{P}=50 \%$ and $\mathrm{P}=64 \%$ ) and humidity of the yeast dough $40,3-42,4 \%$ for the rotational speed of the working element $60 \mathrm{rpm}$. At the rotational speed of the working element of $20 \mathrm{rpm}$ with different moisture content of the yeast dough, porosity values reach $46-50 \%$. For the rotation frequency of the working element $140 \mathrm{rpm}$ at different moisture content of the yeast dough, the porosity reaches $41-52 \%$. 


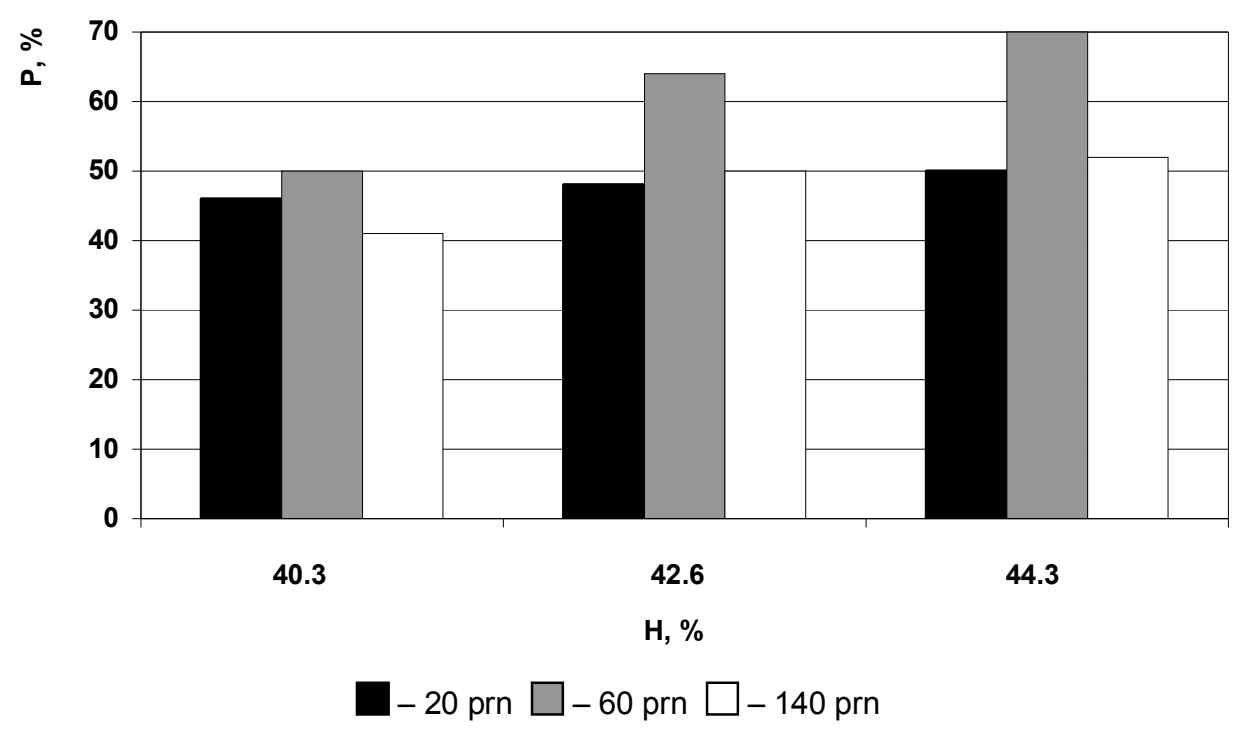

Figure 9. Finished product porosity, depending on the humidity and rotation frequency of the working element

\section{Conclusion}

The yeast dough mixing process of should be carried out at relatively high turns of the working part $60-80 \mathrm{rpm}$, so the humidity in the specified ranges $(40,3-44,3 \%)$ will not significantly affect the process, the gluten macromolecule under the influence of internal stresses appear in the dough, partially destroyed, but due to the internal restructuring of is restored again, and gluten turns out to be elastic. Under these conditions high porosity of the finished product is maintained $\mathrm{P}=70 \%$.

By working element rotation frequency of $60 \mathrm{rpm}$ there recommended indicators for torque drive is not overloaded and reduced energy costs.

\section{References}

1. D’Appolonia B.L., Kunerth W.H. (1984), The Farinograph Handbook, American Association of Cereal Chemist, St. Paul.

2. Kilborn R.H. and Tipples, K.H. (1972), Factors affecting mechanical dough development. II. Implication of mixing at a constant of energy input, Cereal Chem, 49(1), pp. 48-53.

3. Mani K., Eliasson A. C., Lindahl L., Tragardh C. (1992), Rheological properties and bread making quality of wheat flour doughs made with different dough mixers, Cereal Chem. 69(2), pp. 222-225.

4. Pyler E. J. (1988), Baking Science and Technology, Vol. 2, Soslund Publ., Meriam.

5. Mitchell T.A. (1984), Dough mixer controls for the mechanical dough development process, Proceedings of the International Symposium on Advances in Baking Science and Technology, Kansas State University, Manhattan. 
6. Launay B. and Bure J. (1973), Application of a viscometric method to the study of wheat dough, J.Text. Stud. 4(10), pp. 82-101.

7. Wooding A.R., Martin R.J., Wilson A.J., MacRitchie F. (1994), Effect of sulphurnitrogen treat-ments on work input requirements for dough mixing on second season, Proc. 44th RACI Cereal Chemistry Conference.

8. Pareyt B., Brijs K., Jan A. Delcour (2013), Impact of mixing time and sodium stearoyl lactylate on gluten polymerization during baking of wheat flour dough, Food Chemistry, 141, pp. 4179-4185.

9. Hailemariam L., Okos M., Campanella O. (2007), A mathematical model for the isothermal growth of bubbles in wheat dough, Journal of Food Engineering, (82), pp. 466-477.

10. A.Shehzad, Chiron H., Della Valle G., Lamrini B., Lourdin D. (2012), Energetical and rheological approaches of wheat flour dough mixing with a spiral mixer, Journal of Food Engineering, 110, pp. 60-70.

11. Zeppelin Reimelt GmbH (2013), A suitable solution for every mixing task.. // Mixing Technology, Available at: http://www.zeppelin-systems.com/en/productssolutions/mixers.html.

12. Connelly R.K., Kokini J.L. (2007), Examination of the mixing ability of single and twin screw mixers using 2D finite element method simulation with particle tracking, Journal of Food Engineering, 79, pp. 956-969.

13. Iedema P.D., Remerie K., M. van der Hamb (2011), Controlled peroxide-induced degradation of polypropylene in a twin-screw extruder: Change of molecular weight distribution under conditions controlled by micromixing, Chemical Engineering Science, 66, pp. 5474-5486.

14. Uchida K., Okamoto K. (2008), Measurement technique on the diffusion coefficient of powder flow in a screw feeder by X-ray visualization, Powder Technology, 187, pp. $138-145$

15. Chin N., Campbell G. (2005), Dough aeration and rheology: Part 1. Effects of mixing speed and headspace pressure on mechanical development of bread dough, Journal of the Science of Food and Agriculture, 85, pp. 2184-2193.

16. Shehzad A., Chiron H., Della Valle G., Lamrini B. (2012), Energetical and rheological approaches of wheat flour dough mixing with a spiral mixer, Journal of Food Engineering, 110, pp. 60-70.

17. Haraszia R., Larroqueb O.R., Butowb B.J. (2008), Differential mixing action effects on functional properties and polymeric protein size distribution of wheat dough, Journal of Cereal Science, 47, pp. 41-51

18. Jekle M., Becker T. (2011), Dough microstructure: Novel analysis by quantification using confocal laser scanning microscopy, Food Research International, 44, pp. 984991.

19. Kudinova O., Kravchenko O., Lytovchenko I. (2014), Modelling of process in twinscrew dough-mixing machines, Journal of Food and Packaging Science, Technique and Technologies, 5, pp. 64-68.

20. Telychkun Yu., Telychkun V, Kravchenko O. (2013), Perspective direction of complex improvement of rusk wares, Journal of Food and Packaging Science, Technique and Technologies, 2. pp. 67-70. 